\title{
Redesain Tata Letak Taman Bermain Outdoor Santri Raudhatul Atfal dengan Metode Design Thinking yang Ergonomis
}

\author{
Wahyudin Wahyudin*1, Dene Herwanto ${ }^{2}$, dan Billy Nugraha ${ }^{3}$ \\ ${ }^{1}$ Program Studi Teknik Industri, Fakultas Teknik, Universitas Singaperbangsa Karwang, Jl. HS. Ronggo Waluyo, \\ Kecamatan Telukjambe Timur, Kabupaten Karawang, 41361, Indonesia \\ ${ }^{2,3}$ Grup Riset, Universitas Singaperbangsa Karwang, Jl. HS. Ronggo Waluyo, Kecamatan Telukjambe Timur, \\ Kabupaten Karawang, 41361, Indonesia \\ Email: hwwahyudin@gmail.com ${ }^{1}$,deneherwanto@yahoo.com², billynugraha982@gmail.com³
}

\begin{abstract}
Abstrak
Alat bermain di taman kanak-kanak merupakan salah satu fasilitas dan sarana yang perlu mendapatkan perhatian. Mengingat besarnya fungsi dan manfaat alat tersebut dalam aktivitas belajar atau bermain anak-anak. Penelitian ini bertujuan untuk redesain tata letak beberapa alat bermain, diantaranya: perosotan, panjatan globe, dan jembatan lingkar yang ergonomis menurut data antropometri siswa-siswi Taman Kanak-Kanak R.A Nurul Iman. Data tersebut digunakan sebagai parameter dalam membuat rancangan terbaru yang diusulkan secara ergonomis. Langkah-langkah penilitian yang dilakukan dalam merancang alat bermain dengan menggunakan metode design thinking yang ergonomis. Hasil penelitian di dapatkan dari perancangan ulang untuk alat bermain. Rancangan ulang pada permainan perosotan, panjatan globe, dan jembatan lingkar yang disertai dengan ukuran yang sesuai dengan data antropometri siswa-siswi yang di dapat. Terdapat 9 dimensi tubuh yang di ambil dalam penelitian ini dengan metode yang diterapkan, terbagi 3 tahapan: inspiration, ideanation dan implementation.
\end{abstract}

Kata kunci: redesain, antropometri, ergonomis, design thinking

\begin{abstract}
Playground equipment in kindergarten is one of the facilities and facilities that need attention. Given the large function and benefits of these tools in children's learning or playing activities. This study aims to redesign the layout of several playing tools, including: slide, globe climbing, and ergonomic ring bridges according to anthropometric data of R.A Nurul Iman Kindergarten students. This data is used as a parameter in making the latest ergonomically proposed design. The research steps carried out in designing a play tool use an ergonomic design thinking method. The research results were obtained from the redesign of the playing tool. Redesign of the game slide, globe climbing, and ring bridge accompanied by sizes that match the anthropometric data of the students obtained. There are 9 dimensions of the body that are taken in this study with the applied method, divided into 3 stages: inspiration, ideanation and implementation.
\end{abstract}

Keywords: redesign, anthropometric, ergonomic, design thinking

\section{Pendahuluan}

Perkembangan kecerdasan anak, pada usia 5 tahun ke bawah merupakan masa keemasan (golden ages). Salah satu hasil penelitian, menyebutkan pada usia 4 tahun kapasitas kecerdasan anak telah mencapai 50\%, kapasitas $80 \%$ dicapai di usia 8 tahun (Desmita, 2006). Ini menunjukkan pentingnya memberikan perangsangan pada anak usia dini sebelum masuk sekolah. Bahkan anak di usia 1 sampai 5 tahun diketahui punya kemampuan photographic memory, mengingat seperti mata kamera (Broto, 2006). Di usia inilah merupakan waktu yang paling tepat untuk memulai mendidik seorang anak. Dengan memanfaatkan pendidikan di usia dini, anak dikenalkan dengan pola pembelajaran yang menarik dan menyenangkan. Pola pembelajaran yang kreatif akan membuat anak lebih cepat menangkap pembelajaran yang ada. Mereka menjadi senang untuk belajar hal-hal yang baru karena proses pembelajaran terasa seperti bermain (Caroline \& Suproho, 2017). Hal ini terjadi karena perkembangan itu sendiri merupakan suatu proses perubahan yang kompleks, melibatkan berbagai unsur yang saling berpengaruh satu sama lain.

Di kota-kota besar, banyak anak tidak mempunyai halaman untuk bermain sehingga keberadaan taman kota dan taman bermain sangat penting dan sering menjadi satu-satunya tempat anak-anak bermain. Kebutuhan yang tinggi akan ruang bermain beserta fasilitas permainan yang memadai telah menjadi keharusan bagi pemerintah untuk menyediakan jika ingin generasi penerusnya dapat memiliki perkembangan fisik dan mental yang baik (Baskara M. , 2011). Upaya penyedia taman bermain anak-anak yang baik dengan fasilitas yang

\footnotetext{
${ }^{*}$ Penulis utama (Corresponding author)
} 
memadai telah menjadi kesadaran di banyak negara maju namun belum menjadi perhatian utama di negara berkembang seperti di Indonesia. Namun seiring perkembangan waktu, masyarakat Indonesia mulai menyadari akan kebutuhan serta nilai penting keberadaan taman bermain disekitar tempat tinggal. Hal ini di tandai dengan semakin banyaknya taman bermain anak yang disediakan sebagai nilai tambah (daya tarik) kawasan perumahan baru maupun pusat-pusat perbelanjaan (mal) di perkotaan. Upaya penyediaan taman bermain anak jika tidak disertai dengan perencanaan dan perancangan yang matang, selain tujuan penyediaan taman bermain dapat menyimpang juga memberikan resiko kecelakaan bahkan kematian bagi pengguna khususnya anak-anak (Baskara M. , 2011). Oleh karena itu perancangan dan pembangunan taman bermain anak harus mempertimbangkan prinsip pengendalian perancangan yang ergonomis untuk memastikan tingkat keselamatannya. Anak-anak melalui berbagai tahap ditandai berkembangnya cara bermain saat mereka tumbuh. Sementara itu, perlu dipahami tahapan ini dalam rangka untuk menciptakan ruang bermain yang cocok untuk masing-masing kelompok umur.

Penjelasan pada gambar di atas di bawah ini sesuai dengan tingkatan usia pada anak (Broto, 2006), berikut diantaranya:

a. 0-3 Tahun, anak-anak memperoleh pengalaman formatif mereka dan belajar untuk mengontrol gerakan mereka sendiri dalam 3 tahun pertama kehidupan mereka. Mereka selalu bermain sendiri dan cenderung ke arah eksperimen dengan sentuhan, penglihatan dan suara. Bermain di pasir, tanah liat, ayunan dan slide (dua terakhir dengan bantuan orang dewasa) adalah permainan yang sesuai dengan tahap ini.

b. 3-6 Tahun, antara usia tersebut sudah mulai muncul kesadaran sosial. Sehingga anak-anak selalu bermain dalam kelompok. Mereka mencoba membina hubungan interpersonal dan sosialisasi. Anak-anak dalam kelompok usia ini menikmati kegiatan yang mewakili sesuatu yang lain. Misalnya: mereka bermain dengan unsur-unsur abstrak, tabel, bangku, serta dengan ayunan, slide dan peralatan bergerak.

c. 6-8 Tahun, anak tertarik memilih kegiatan yang melibatkan gerakan dan tindakan. Misalnya: kegiatan yang mengembangkan baik organisasi dan keterampilan fisik. Anak-anak dalam kelompok usia ini menikmati menguji ketangkasan mereka dengan unsur-unsur seperti memanjat jaring dan lebih atau kurang struktur yang kompleks lain yang memanggil respon motorik yang berbeda.

d. 8-10 Tahun, mulai mendekati masa remaja. Anak-anak memilih berkelompok bersama, tapi tanpa pengawasan orang dewasa atau gangguan dari anak-anak muda. Permainan terstruktur dengan tujuan aturan bermain kelompok atau tim cenderung mendominasi pada usia ini. Mereka juga ingin menunjukkan kekuatan mereka, keseimbangan dan koordinasi lebih dalam peralatan panjat yang rumit.

Istilah ergonomi berasal dari bahasa latin yaitu ergon yang berarti kerja dan nomos yang berarti hukum alam dan dapat didefinisikan sebagai studi tentang aspek-aspek manusia dalam lingkungan kerjanya yang ditinjau secara anatomi, fisiologi, psikologi, engineering, manajemen dan desain/perancangan (Bridger, 1995). Ergonomi berkenaan pula dengan optimasi, efesiensi, kesehatan, keselamatan dan kenyamanan manusia di tempat kerja, di rumah, dan tempat rekreasi. Di dalam ergonomi dibutuhkan studi tentang sistem dimana manusia, fasilitas kerja dan lingkungannya saling berinteraksi dengan tujuan utama yaitu menyesuaikan suasana kerja dengan manusianya (Dieter, 2000). Bahwa performarsi atau kemampuan kerja seseorang pekerja tergantung dari perbandingan antara besarnya tuntutan kerja terhadap besarnya kemampuan pekerja tersebut (Tarwaka, Ergonomi Industri, 2010), berikut diantaranya:

a. Tuntutan tugas jauh lebih besar dibandingkan kemampuan atau kapasitas pekerja, maka dapat menyebabkan dampak overstress, kecelakaan kerja, kelelahan, cidera, penyakit, rasa sakit dan lain-lain.

b. Tuntutan tugas yang lebih rendah dari kemampuan pekerja, maka akan berakibat understress, kejenuhan, kebosanan dan lain-lain.

c. Tuntutan tugas yang seimbang dengan kemampuan pekerja, maka akan mencapai suatu kondisi keja yang nyaman, aman dan juga produktif.

Selain itu, secara umum dalam prinsip-prinsip ergonomi terbagi atas 5 point (Dieter, 2000), berikut diantaranya:

a. Kegunaan atau Utility, artinya setiap produk yang dihasilkan memiliki manfaat kepada seseorang dalam mendukung aktivitas atau kebutuhan secara maksimal tanpa mengalami suatu kesulitan ataupun masalah dalam kegunaannya.

b. Keamanan atau Safety, artinya setiap produk yang dihasilkan memiliki fungsi dan manfaat tanpa resiko yang membahayakan keselamatan ataupun yang ditimbulkan dapat merugikan bagi pemakainya.

c. Kenyamanan atau Comfortability, artinya produk yang dihasilkan memiliki tujuan yang sesuai atau tidak menggangu aktivitas dan upaya mendukung aktivitas seseorang. 
d. Keluwesan atau Flexibility, artinya dapat digunakan untuk kebutuhan dalam kondisi ataupun fungsi ganda.

e. Kekuatan atau Durability, artinya harus awet dan juga tahan lama dan tidak mudah rusak jika digunakan. Berdasarkan hasil observasi, maka tujuan penelitian ini akan membuat rancangan ulang peralatan bermain di Taman Kanak-kanak Nurul Iman. Fasilitas bermain yang akan dirancang ulang antara lain perosotan, panjatan globe, dan jembatan lingkar. Fasilitas bermain yang baik harus dirancang dengan aman dan nyaman sehingga tidak menimbulkan potensi bahaya bagi anak-anak (Nofirza \& Infi, 2011). Pada semua fasilitas bermain tersebut akan direkomendasikan rancangan yang ergonomis. Inti dari ergonomi adalah suatu prinsip bahwa pekerjaanlah yang harus disesuaikan dengan kemampuan dan keterbatasan yang dimiliki oleh manusia (fitting the job to the man) (Gempur, 2004). Ini berarti dalam merancang suatu jenis pekerjaan, perlu diperhitungkan faktor-faktor apa saja yang menjadi kelebihan dan keterbatasan manusia sebagai pelaku kerja. Salah satu faktor keterbatasan manusia yang harus dipertimbangkan adalah keterbatasan dalam ukuran dimensi tubuh (Pheasant, 1988).

\section{Metode Penelitian}

Langkah awal dalam penelitian ini adalah melakukan pengumpulan data. Data yang dikumpulkan merupakan data antropometri siswa-siswi Taman Kanak-kanak Nurul Iman sebanyak 56 orang. Data antropometri yang dikumpulkan selanjutnya diolah dengan melakukan pengujian statistik meliputi: pengujian keseragaman data, pengujian kenormalan data, pengujian kecukupan data dan perhitungan atau penentuan persentil. Kemudian dengan memperhatikan konsep perancangan produk dilakukan perancangan alat belajar/bermain dengan menyesuaikan dengan data antropometri yang didapatkan. Langkah terakhir adalah melakukan analisis terhadap hasil rancangan, pada tahap ini dilakukan perbandingan antara alat yang dirancang dengan alat yang sudah ada. Maka kesimpulan akan didapatkan ketika alat belajar/bermain yang dibuat dengan memperhatikan aspek ergonomi.

Jenis data yang digunakan dalam penelitian ini adalah data primer dan data sekunder (Sutalaksana, 1979). Adapun data primer yang diambil (Tarwaka, Ergonomi Industri, 2010), berikut diantaranya:

a. Pengumpulan data dengan cara mengamati secara langsung perilaku anak sewaktu anak menggunakan fasilitas bermain outdoor seperti perosotan, panjatan globe, dan jembatan lingkar.

b. Pengumpulan data dengan cara mengukur dimensi fasilitas bermain outdoor menggunakan alat ukur meteran. Data yang didapat dari pengukuran ini nantinya untuk mengevaluasi tingkat keergonomisan fasilitas bermain dengan membandingkan ukuran fasilitas dan dimensi tubuh anak.

Adapun data sekunder yang diperoleh dari penelitian pustaka, dengan cara mempelajari teori-teori dan informasi yang erat hubungannya dengan penelitian yang sedang dilaksanakan (Tarwaka, Ergonomi Industri Revisi Edisi II, 2014). Landasan dalam beberapa prinsip pengendalian perancangan untuk mewujudkan taman bermain anak yang sesuai dan ideal. Maka pengendalian terhadap perancangannya dilandaskan fungsi taman bermain sebagai wilayah pengembangan kreativitas, jiwa sosial, indera dan pengembangan diri anak. Sehingga dapat memperoleh kesenangan (fun), untuk itu perancangan taman bermain anak harus (Baskara M. , 2011), berikut diantaranya:

a. Menjamin keselamatan, keamanan dan kesehatan anak untuk bermain di ruang publik.

b. Menciptakan kenyamanan dan kemudahan bagi semua anak (sehat maupun dengan keterbatasan fisik dan mental).

c. Menciptakan keharmonisan estetika visual dengan karakter kawasan disekitarnya. Taman bermain dapat dikembangkan sebagai fasilitas penunjang maupun fasilitas utama di ruang publik.

d. Memberikan kejelasan tentang fungsi peralatan permainan dan kekuatan kontruksinya.

Metode design thinking yang akan diterapkan dalam penelitian ini menurut Bryan Lawson terbagi menjadi 3 tahapan. Seperti Gambar 2. di bawah ini.

THE DESIGN THINKING PROCESS

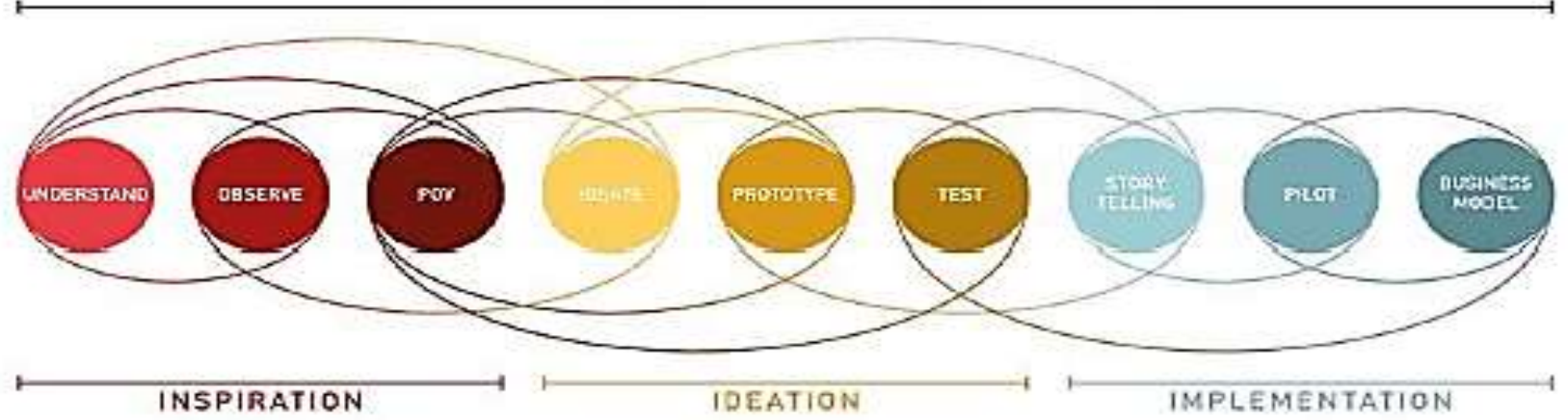

Gambar 2. Metode Design Thinking 
Penjelasan dari Gambar 2. di atas untuk metode design thinking (Lawson, 2005), berikut diantaranya:

a. Inspiration, pada tahap understand. Tahap pertama penelitian ini memahami masalah dan kebutuhan sesuai tempat studi kasus. Kemudian melakukan studi literatur pada buku dan jurnal. Tahap selanjutnya adalah observe, penulis melakukan studi lapangan atau survei terkait tempat studi kasus tersebut. Selain itu melakukan wawancara, dokumentasi, dan pengamatan pada aktivitas anak-anak. Selanjutnya tahap terakhir adalah point of view. Penulis menemukan solusi dan kebutuhan dari aktivitas anak-anak.

b. Ideanation, pada tahap kedua penelitian ini solusi yang didapat kemudian diaplikasikan ke dalam konsep. Kemudian disketsakan dari inspirasi-inspirasi yang didapat dari internet dan dari sketsa alternatif dipilih yang dapat menjawab kebutuhan anak-anak secara detail. Tahap selanjutnya prototype, desain yang ada kemudian dibuat maket sesuai skala untuk mengetahui besar yang sesuai dengan ruangan maupun sirkulasi. Tahap terakhir adalah test, desain yang ada akan diujikan dan dievaluasi oleh diri sendiri dan orang lain untuk mengetahui kekurangan desain agar memperoleh hasil yang optimal.

c. Implementation, pada tahap ini story telling. Pada tahap ketiga penelitian ini akan mempresentasikan atau menceritakan hasil desain kepada pengguna yang diharapkan dapat menjadi kebutuhan masyarakat tempat studi kasus tersebut. Tahap selanjutnya pilot, desain yang dapat dinyatakan berhasil jika menjawab kebutuhan dan masalah, sedangkan desain dinyatakan gagal jika tidak menjawab kebutuhan dan masalah. Tahap terakhir adalah business model, penulis berharap desain dapat menguntungkan bagi pihak yang terlibat.

Esensi dasar dari evaluasi ergonomi dalam proses perancangan desain adalah sedini mungkin mencoba memikirkan kepentingan manusia agar bisa terakomodasi dalam setiap kreativitas dan inovasi sebuah ' $m a n$ made object' (Wignjosoebroto, 2008). Fokus perhatian dari sebuah kajian ergonomis akan mengarah ke upaya pencapaian sebuah perancanganan desain suatu produk yang memenuhi persyaratan 'fitting the task to the man' (Whitten, Bentley, \& Dittman, 2004), sehingga setiap rancangan desain selalu memikirkan kepentingan manusia, perihal keselamatan, kesehatan, keamanan maupun kenyamanan (Wignjosoebroto, 2008).

\section{Hasil dan Pembahasan}

Rujukan pustaka Pengambilan data dilakukan pada 56 siswa-siswi Taman Islam, dan guna memudahkan perhitungan data tersebut. Maka 56 data tersebut dibagi ke dalam delapan sub-group (kelompok) dan setiap subgrup terdapat tujuh orang. Dimensi tubuh yang diukur dalam menentukan letak dan nilai persentil yang digunakan sebagai parameter. Terdapat 9 dimensi tubuh yang di ambil dalam penelitian ini, sesuai dengan alat belajar/bermain yang akan dibuatkan ulang. Dengan penjelasan pada saat posisi tubuh berdiri, data dimensi tubuh yang diambil yaitu:

a. Berat Badan,

b. Tinggi Badan Tegak,

c. Panjang Rentangan Tangan ke Atas, dan

d. Jangkauan Tangan ke Atas.

Sedangkan pada saat posisi tubuh duduk, data dimensi tubuh yang diambil yaitu:

a. Tinggi Popliteal,

b. Tinggi Duduk Tegak,

c. Lebar Pinggul,

d. Bahu bagian Atas, dan

e. Panjang Popliteal.

Dalam mendapatkan letak dan nilai persentil ada beberapa tahapannya, dimulai dari: uji kenormalan data, uji statistik, uji keseragaman data, uji kecukupan data dan uji persentil. Dalam pengujian tersebut terdapat beberapa langkah-langkah yang semuanya saling berkaitan. Dimulai pada uji kernormalan data, dimulai dari menghitung range, menghitung banyaknya kelas interval dan menghitung panjang kelas interval (Myers, 1995). Namun pada saat ini terdapat beberapa kelemahan dalam artian kurang memperhatikan aspek-aspek ergonomi diantaranya (Nurmianto, 2008), berikut diantaranya:

a. Pada permainan perosotan, lantai perosotan terlalu lebar dan tidak di sesuaikan dengan lebar pinggul anakanak dan tinggi pembatas dinding perosotan yang terlalu tinggi.

b. Panjatan globe, jarak antara pegangan tangan atau pinjakan kaki terlalu lebar, yang tidak menyesuaikan dengan tubuh anak-anak pada umumnya.

c. Jembatan lingkar, pegangan tangan pada jembatan tidak sesuai dengan ukuran tinggi tubuh siswa.

Berikut hasil tampilan dalam bentuk 2-dimensi (kondisi awal) atau yang menunjukkan kondisi alat bermainan sekarang. Dalam ukuran yang masih kurang ergonomis untuk digunakan: 


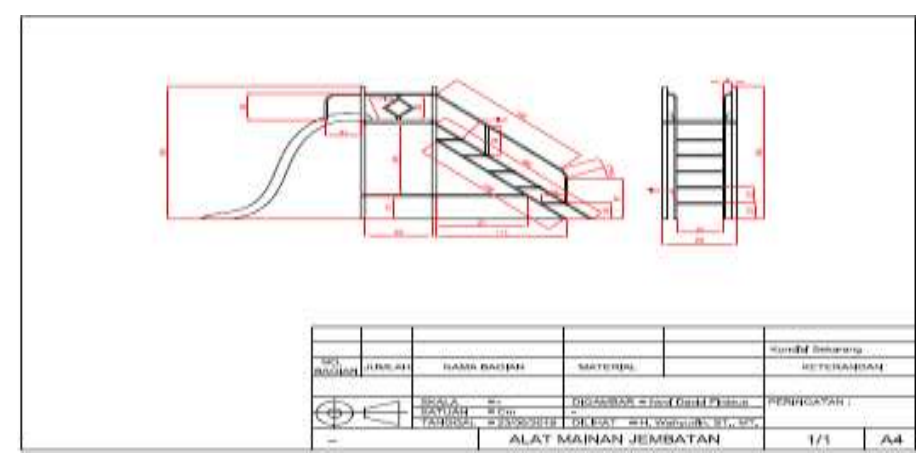

Gambar 3. Tampilan 2-D Perosotan (Kondisi Awal)

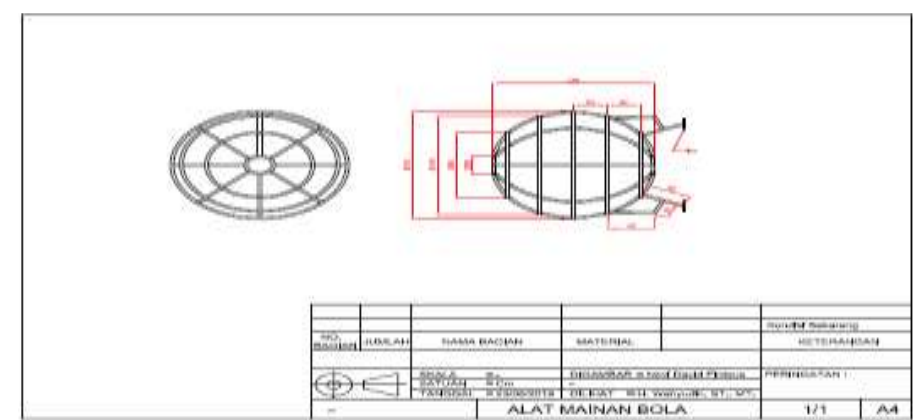

Gambar 4. Tampilan 2-D Panjatan Globe (Kondisi Awal)

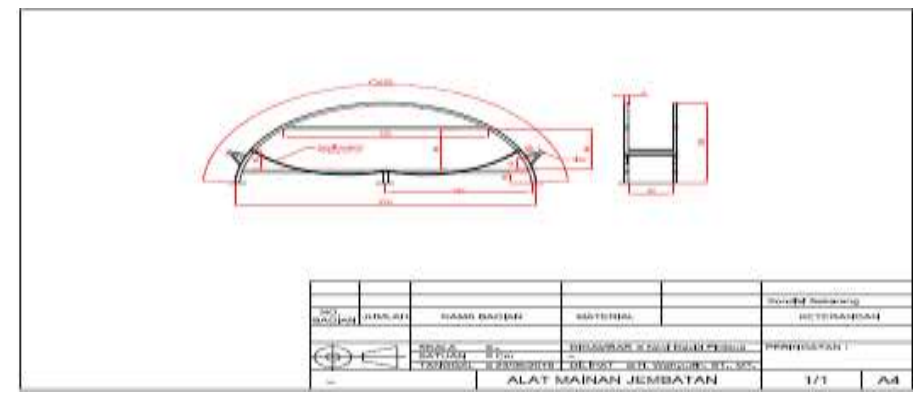

Gambar 5. Tampilan 2-D Jembatan Lingkar (Kondisi Awal)

Berikut hasil tampilan dalam bentuk 2-dimensi (usulan) atau yang menunjukkan kondisi alat bermainan usulan. Dalam ukuran yang mengikuti prinsip ergonomis untuk digunakan:

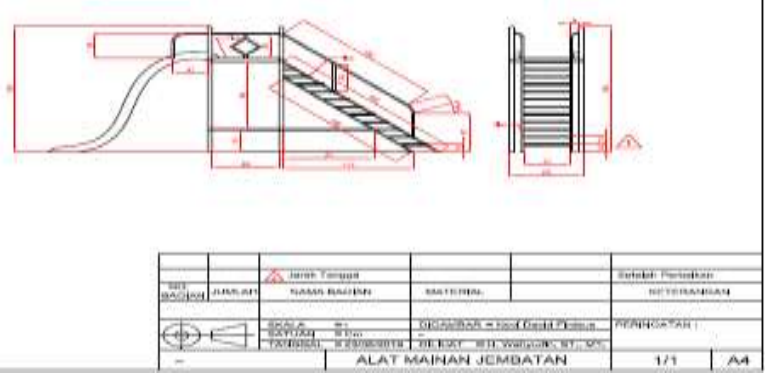

Gambar 6. Tampilan 2-D Perosotan (Usulan Rancangan Terbaru)

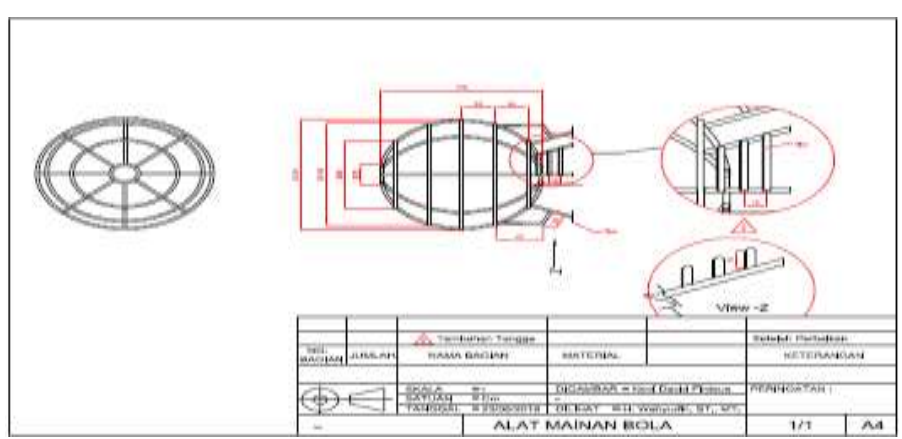

Gambar 7. Tampilan 2-D Panjatan Globe (Usulan Rancangan Terbaru) 


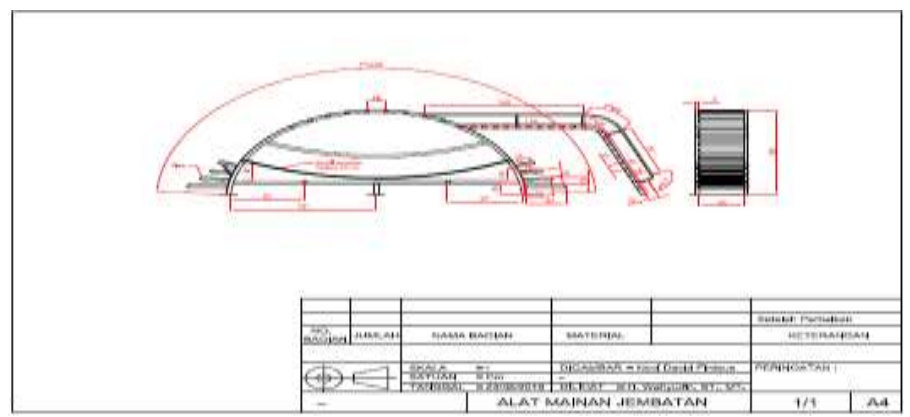

Gambar 8. Tampilan 2-D Jembatan Lingkar (Usulan Rancangan Terbaru)

Berikut hasil tampilan dalam bentuk 2-dimensi redesain tata letak atau yang menunjukkan kondisi alat bermainan. Dalam ukuran yang mengikuti metode yang akan diterapkan:

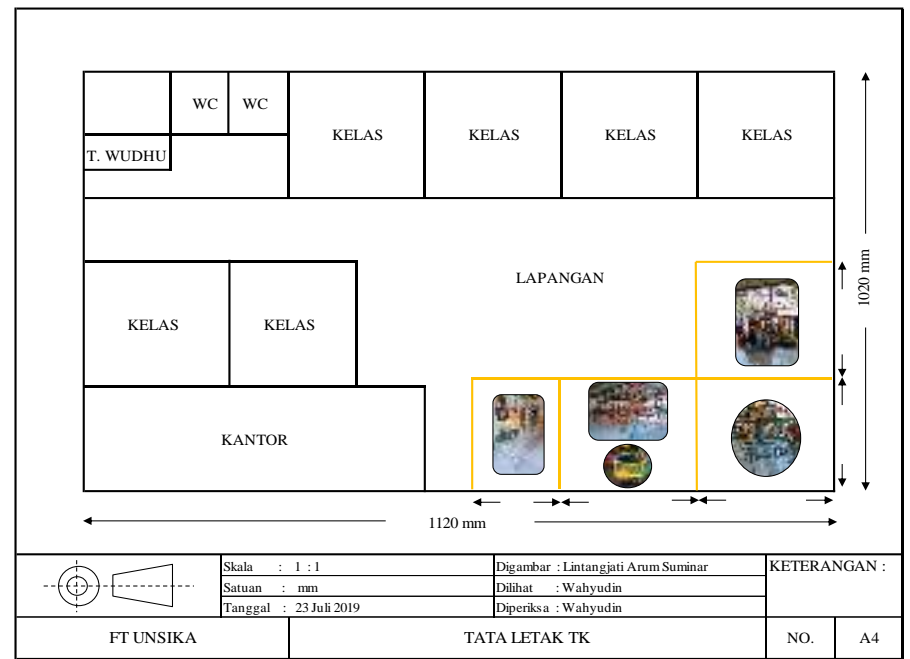

Gambar 9. Hasil Redesain 2-Dimensi

Berikut hasil tampilan dalam bentuk 3-dimensi redesain tata letak atau yang menunjukkan kondisi alat bermainan. Dalam ukuran yang mengikuti metode yang akan diterapkan:

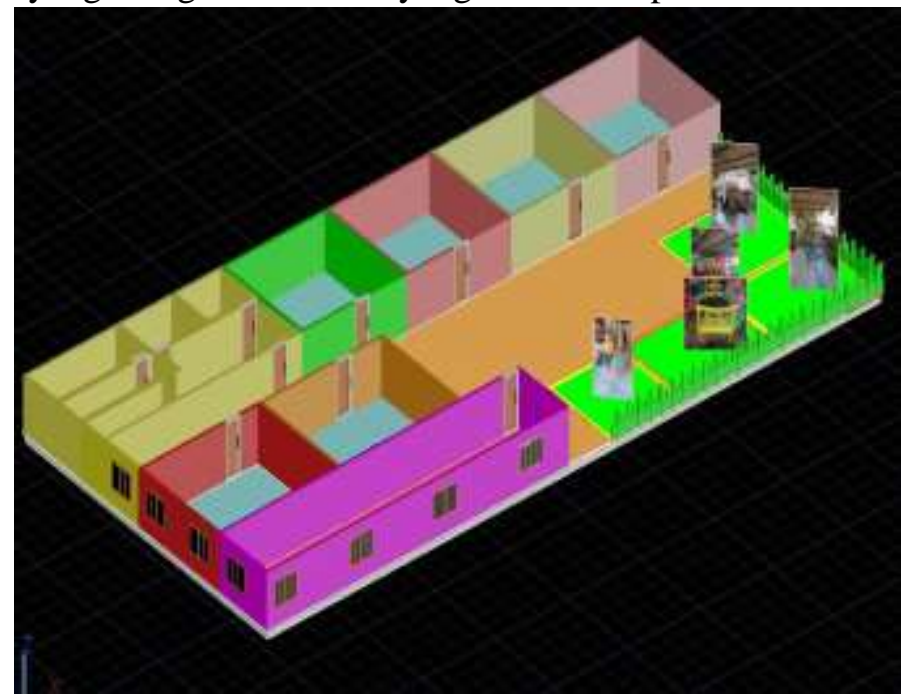

Gambar 10. Hasil Redesain 3-Dimensi

\section{Simpulan}

Dari hasil penelitian yang sudah dilakukan, maka didapatkan hasil perancangan ulang untuk alat bermain atau belajar. Rancangan ulang pada permainan perosotan, panjatan globe, dan jembatan lingkar yang disertai dengan ukuran yang sesuai dengan data antropometri siswa-siswi yang didapat. Dengan adanya rancangan alat belajar atau bermain yang disesuaikan dengan kebutuhan siswa-siswi Taman Kanak-kanak Nurul Iman diharapkan dapat memberikan stimulus untuk pengembangan kemampuan motorik anak-anak, dan bagi orang tua juga lebih merasa lebih aman karena anak-anak dapat bermain dengan alat belajar atau bermain dengan aman dan nyaman (Baskara M. , 2011). 
Dengan adanya penelitian ini diharapkan dapat menjadi sumber ide bagi peneliti-peneliti yang ingin mendalami permasalahan ini selanjutnya untuk menghasilkan suatu penelitian yang lebih tuntas (Liliana, 2007). Penelitian lanjutan dapat dilakukan seperti meneliti jenis dan bentuk yang sesuai untuk digunakan, kekuatan bahan, besar biaya yang dibutuhkan, bentuk rancangan, ataupun produk jadi yang bisa diujikan kepada siswa-siswi tersebut. Sehingga konsep perancangan produk yang diterapkan dalam metodologi penelitian dapat selesai dengan menyeluruh.

Saran untuk penelitian selanjutnya adalah mengidentifikasi semua fasilitas bermain outdoor yang ada di Taman Kanak-kanak serta diharapkan untuk mengembangkan penelitian ini dengan dilengkapi prototype dan perhitungan jadwal perawatan pada fasilitas bermain terutama pada besi dan kawat permainan.

\section{Daftar Pustaka}

Baskara, M. (2011). Prinsip Pengendalian Perancangan Taman Bermain Anak di Ruang Publik. Jurnal Lanskap Indonesia, III(1), 20-28.

Baskara, M. (2011). Prinsip Pengendalian Perancangan Taman Bermain Anak di Ruang Publik. Jurnal Laskap Indonesia, III(1), 5-7.

Bridger, R. S. (1995). Introduction to Ergonomics. Singapore: McGraw Hill Inc.

Broto, C. (2006). Design for Fun: Play Space2006. Singapore: Page One Publishing Private Limited.

Caroline, S., \& Suproho, F. P. (2017). Perancangan Interior Fasilitas Dolanan Edutainment untuk Anak Usia 4-12 Tahun di Surabaya. Jurnal Intra, V(2), 871-889.

Desmita. (2006). Psikologi Perkembangan. Bandung: PT. Remaja Rosdakarya.

Dieter, G. E. (2000). Engineering Design : A Material \& Processing Approach 3rd Edition. Maryland: McGraw Hill Inc.

Gempur, S. (2004). Ergonomi Manusia, Peralatan, dan Lingkungan. Jakarta: Prestasi Pustaka Publisher.

Lawson, B. (2005). How Designer Think. Dalam Ergonomic for Childern (hal. 178-182). New York: Taylor \& Francis Group.

Liliana, Y. P. (2007). Pertimbangan Ergonomi pada Pendisainan. Jurnal Sekolah Teknologi Nuklir, III(1), 5062.

Myers, E. R. (1995). Ilmu Peluang dan Statistika untuk Insinyur dan Ilmuan. Bandung: ITB.

Nofirza, \& Infi, Z. (2011). Perancangan Alat Belajar dan Bermain yang Ergonomis di Taman Kanak-Kanak Islam Permata Selat Panjang. Jurnal Ilmiah Teknik Industri, X(1), 48-58.

Nurmianto, E. (2008). Ergonomi Konsep Dasar dan Aplikasinya. Jakarta: PT Guna Wijaya.

Pheasant, S. (1988). Bodyspace, Anthropometry, Ergonomics and Design. London: Taylor \& FrancisInc.

Sutalaksana, I. Z. (1979). Teknik Tata Cara Kerja. Bandung: MTI ITB.

Tarwaka. (2010). Ergonomi Industri. Surakarta: Harapan Press.

Tarwaka. (2014). Ergonomi Industri Revisi Edisi II. Surakarta: Harapan Press.

Whitten, J. L., Bentley, L. D., \& Dittman, K. C. (2004). Metode Desain dan Analisis Sistem. Yogyakarta: Tim Penerjemah ANDI.

Wignjosoebroto, S. (2008). Ergonomi (Studi Gerak dan Waktu). Surabaya: Guna Widya. 
Halaman kosong 